\title{
Effect of concentrate type (starch vs. fiber) and bicarbonate addition in grass silage-based diets on performance, diet digestibility and enteric methane emissions in lactating dairy cows.
}

\author{
Joint Annual Meeting ASSA-ADSA-CSAS-WSASAS 2016, Salt Lake City, UT. \\ Saturday, July 23, 2016: 9:45 AM \\ 155 E (Salt Palace Convention Center)
}

\begin{abstract}
Adeline Bougouin, INRA-UMR1213 Herbivores, Saint-Genes-Champanelle, France Anne Ferlay, INRA-UMR1213 Herbivores, Saint-Genes-Champanelle, France Michel Doreau , INRA-UMR1213 Herbivores, Saint-Genes-Champanelle, France Yvanne Rochette, INRA-UMR1213 Herbivores, Saint-Genes-Champanelle, France Sylvie Rudel, INRA-UMR1213 Herbivores, Saint-Genes-Champanelle, France Clothilde Lascoux , INRA-UMR1213 Herbivores, Saint-Genes-Champanelle, France Cecile Martin , INRA-UMR1213 Herbivores, Saint-Genes-Champanelle, France
\end{abstract}

\begin{abstract}
Text:
Cereals and corn silage diets are extensively used for high yielding dairy cows and it is well established that altering dietary starch and fiber proportion results in methane $\left(\mathrm{CH}_{4}\right)$ emissions mitigation. With grass silage-based diets, quantitative evidence of $\mathrm{CH}_{4}$ emissions reduction with high-starch concentrate is lacking. Therefore, the objective was to compare the effects of fiber-rich (F) or starch-rich (S) diets based on grass silage, supplemented or not with bicarbonate (Fb and $\mathrm{Sb}$ ) on $\mathrm{CH}_{4}$ emissions, diet digestibility and performance in dairy cows. Four multiparous lactating Holstein cows were used in a $4 \times 4$ Latin-square design experiment of 4 periods of 4 weeks each. Four dietary treatments were assigned based on grass silage $42 \%$, hay $8 \%$, and $\mathrm{F}$ or $\mathrm{S}$ concentrate $50 \%$ (DM basis), supplemented or not with sodium bicarbonate (1\% DMI). Bicarbonate was used as a digestive regulator to lower the risk of ruminal acidosis appearance. Intake and milk production were measured daily and milk composition weekly during the experiment. Methane production and diet digestibility were measured simultaneously for the last 5-d of each period when cows were in open respiration chambers. Feed efficiency (fat and protein corrected milk/DMI) was calculated using data from week-4. Data were analyzed using mixed-effect models with cows as randomeffect, period and treatments as fixed-effects. Orthogonal contrasts were used to evaluate diet type or bicarbonate supplementation effects. The $\mathrm{S}$ and $\mathrm{Sb}$ diets induced less daily $\mathrm{CH}_{4}$ emissions (417.5 and 393.9 g.d $^{-1}$, respectively) than $\mathrm{F}$ and $\mathrm{Fb}$ diets (487.9 and 506.4 g.d-1 ${ }^{-1}$, respectively) as well as a significant decrease in $\mathrm{CH}_{4}$ intensity $\left(-14 \%\right.$ in g.DMl-1; $-20 \%$ in g.FPCM $\left.^{-1}\right)$. DMl was reduced by $3.5 \%$ with the starch-diets compared to fiber-diets $(P<0.05)$. Total tract digestibility of nutrients (DM, OM, Starch) and gross energy were lower $(P<0.05)$ for $\mathrm{F}$ and $\mathrm{Fb}$ than for $\mathrm{S}$ and $\mathrm{Sb}$ diets. Feed efficiency, milk yield and fat content were not different between starch- and fiber-diets $(P>0.05)$ but milk protein content was greater for the starch-diets $(+3 \%, P<0.05)$. Bicarbonate had no effect on diet digestibility and $\mathrm{CH}_{4}$ emissions $(P>0.05)$. However, milk fat content was higher $(P=0.05)$ with $\mathrm{Sb}$ than $\mathrm{S}, \mathrm{F}$ and $\mathrm{Fb}$ diets. Feeding $50 \%$ starch-rich concentrate with grasssilage diets, with or without bicarbonate, is an effective dietary approach for reducing methane emissions without altering diet digestibility and milk performance of dairy cows.
\end{abstract}

Keywords: concentrate type, dairy cow, methane emissions 